\title{
Validation of UV-Vis Spectrophotometric Method of Quercetin in Ethanol Extract of Tamarind Leaf
}

\section{Erma Yunita*, Deni Yulianto, Siti Fatimah, Tirsa Firanita}

Akademi Farmasi Indonesia, J. Veteran Gg. Jambu, Pandeyan, Umbulharjo, Kota Yogyakarta, Daerah Istimewa Yogyakarta 55161.

\begin{abstract}
Tamarindus indica $L$ is a medicinal plant that has many benefits. One of the chemical compounds contained therein is the flavonoid quercetin type. The number of herbal products on the market makes the quality assurance of herbal products need to be done by performing the assay of the active compounds using validated methods. This study aims to validate the assay method quercetin in the extract of tamarind leaves. Tamarind leaf extract was macerated with hexane; then, it was re-macerated with $70 \%$ ethanol. The extract was concentrated using a rotary evaporator. The assay was performed using the UV-Vis Spectrophotometry method, and parameter validation specified in this study, including linearity, LOD, LOO, precision, and accuracy. Quercetin level obtained in extracts of tamarind leaves was at $21.52 \mathrm{mg} / \mathrm{g}$. Based on the test method validation, the correlation coefficient ( $r$ ) was 0.9999 , the regression function coefficients $\left(V x_{0}\right)$ was $0.59545 \%$, LOD 0.1515 ppm, LOO 0.4592 ppm, coefficient of variation precision was $<2 \%$, and recoveries range was in $97-103 \%$.
\end{abstract}

Keywords: Tamarind; Tamarindus indica L.; UV-Vis Spectrophotometric; Validation

\section{Data of article}

Received : 24 Feb 2020

Reviewed : 12 May 2020

Accepted : 4 Jul 2020

\section{DOI}

10.18196/jfaps.010102

\section{Type of article:}

Research

\footnotetext{
*Corresponding author, e-mail: ermayunita@afiac.id
} 


\section{INTRODUCTION}

Tamarindus indica $L$. can be used for many purposes, such as herbs, medicinal materials, and cosmetics. Furthermore, tamarind fruit pulp can be used as a mixture of traditional medicine and herbs. ${ }^{1,2}$ Flavonoid compounds contained in tamarind leaves are a kind of flavonoid quercetin. Quercetin has potential as antiviral, antibacterial, and antiinflammatory. ${ }^{1}$ Quercetin has a good antibacterial activity for the phenol group with protein coagulation mechanism by deactivating enzymes and disrupting the cell wall; thus, it has good bactericidal properties. ${ }^{3}$ Quercetin in plants is in various forms of glycosides. ${ }^{4}$

There are a considerable amount of benefits of tamarind leaves, which can increase the development of product innovation. 5 Quality assurance of herbal products can be done by performing the assay of the active compounds using methods that have been validated. ${ }^{6}$ The current widely used analytical method is the UV-Vis spectrophotometry method. The method provides a simple way to determine the quantity of a little substance. The method used in the assay should be validated. Validation of the methods of analysis is an assessment of the actions of certain parameters based on laboratory experiments. This activity is carried out to prove the parameters used to meet the requirements for its use. Validation can also be used to identify the source of the unwanted variability. ${ }^{7}$

\section{METHODS}

The material used in this study was tamarind leaves (Tamarindus indica L.) from Mantrijeron, Yogyakarta. Other materials used included ethanol pro analysis (Merck), 70\% ethanol (CV.
General Labora), filter paper, Quercetin (Sigma Aldrich), aquadest (CV. General Labora), and aluminum foil. The analysis instrument used in this study was the Genesys 10S UV-Vis Spectrophotometer.

Preparation of Tamarind Leaves Extract Tamarind leaf was macerated with nhexane then stirred using an electric stirrer for 1 hour. It was then soaked for 24 hours. The results of the maceration were filtered. The residue obtained was then dried and macerated by $70 \%$ ethanol and then stirred using an electric stirrer for 1 hour. The soaking process was conducted for 24 hours to protect it from light, while it was occasionally stirred. The results of maceration were filtered to separate the pulp and filtrate. The macerating process was concentrated by a rotary evaporator and thickened above the water bath until a thick extract was formed. The ethanol extract could be calculated for its yield.

Rendemen calculation $=\frac{\text { g Extract }}{\mathrm{g} \text { Simplicia }} \times 100 \%$

\section{Preparation of stock solutions}

The stock solution of quercetin and tamarind leaf extract wasmade at a concentration of $10,000 \mathrm{ppm}$. Stock solutions were created using Ethanol pa.

\section{Determination of maximum wavelength}

The stock concentration of $100 \mathrm{ppm}$ as much as $\pm 3 \mathrm{ml}$ was measured with a spectrophotometer at a wavelength of 200-800 nm.

\section{Preparation of quercetin standard curve} The standard curve was created by connecting the standard solution concentration in the series concentration of 4 ppm, 6 ppm, 8 ppm, 10 ppm, and 12 ppm with the absorption results obtained from the measurement using UV-Vis spectrophotometry at maximum wavelength. $^{8}$ 


\section{Determination of my quercetin levels in the tamarind leaf extract}

Tamarind leaf extract of a concentration of $500 \mathrm{ppm}$ measured its absorbance using UV-Vis spectrophotometry at a maximum wavelength. Sample solutions were made in 3 trials.

\section{Validation of Analysis Methods}

Linearity was conducted by measuring the absorbance of the comparison solution. Furthermore, the curve of the relationship between concentration vs. absorption and the linear regression equation and the correlation coefficient $(x)$ and the correlation coefficient of the function $\left(\mathrm{V}_{\mathrm{xo}}\right)$ were determined. The regression function coefficient $\left(V_{x o}\right)$ can be calculated using the formula below. ${ }^{6}$

$$
\begin{aligned}
& \mathrm{S}_{\mathrm{y} / \mathrm{x}}=\sqrt{\frac{\sum(\mathrm{yr}-\mathrm{Y})^{2}}{\mathrm{n}-2}} \\
& \mathrm{~S}_{\mathrm{xo}}=\frac{\mathrm{syfx}}{\mathrm{b}} \\
& \mathrm{V}_{\mathrm{xo}}=\frac{\mathrm{Sy} / \mathrm{x}}{\overline{\mathrm{x}}} \times 100 \%
\end{aligned}
$$

Information:

$$
\begin{array}{ll}
\text { yr } & \text { : Absorbance } \\
\mathrm{S}_{\mathrm{y} / \mathrm{x}} & \text { : Residual standard deviation }
\end{array}
$$

The correlation coefficient is considered to be good if $r$ has a value of $\geq 0.998$. The regression function coefficient $\left(V_{x o}\right)$ is deemed to be good if it has a value of $\leq$ $5 \%$.

Limit of detection and limit of quantitation can be calculated statistically through linear regression lines from the calibration curve. The measurement value will be the same as the value of $b$ in the linear line equation $y=a+b x$, while the standard deviation of the blank is the same as the residual standard deviation $\left(\mathrm{S}_{\mathrm{y} / \mathrm{x}}\right)$ or by the formula below. ${ }^{6}$

$$
\operatorname{LOD}=\frac{3,3 \times \mathrm{Sy} / \mathrm{x}}{\mathrm{b}}
$$

$$
\mathrm{LOQ}=\frac{10 \mathrm{x} \text { Sy } / \mathrm{x}}{\mathrm{b}}
$$

Information:

$\mathrm{S}_{\mathrm{y} / \mathrm{x}} \quad$ : Residual standard deviation

b : Response from slope (slope in line equation $y=b x+a$ )

Precision is carried out by measuring the absorbance of the test solution, and then the percentage of correlation coefficients was calculated to identify the reproducibility of the system used CV requirements $<2 \% 6$. Testing was conducted 7 times.

Accuracy in this study was carried out by the standard addition method. The comparison between the extract and the standard is $70: 30$ with a range of $80 \%$, $100 \%$, and $120 \%$. The absorbance of the solution was measured using a UV spectrophotometer at a maximum wavelength, and the experiment was carried out 3 times. Accuracy testing was calculated as percent recovery using the formula:

Information:

$$
\text { Percent recovery }=\frac{C_{F}-C_{A}}{C_{A}^{*}} \times 100 \%
$$

$\mathrm{C}_{\mathrm{F}}$ : Total sample concentration obtained from measurements

$\mathrm{C}_{\mathrm{A}}$ : The actual sample concentration

$\mathrm{C}^{*} \mathrm{~A} \quad$ : The concentration of the analyte added

\section{RESULTS AND DISCUSSION}

Tamarind leaf extract was carried out using the maceration method. Maceration is the most widely used simple method. This method is carried out by inserting the appropriate plant powder and solvent into an inert container, which is tightly closed at room temperature. 9 Maceration was conducted using n-hexane solvent and then macerated again using $70 \%$ ethanol. 
Extraction with $\mathrm{n}$-hexane solvent aimed to dissolve chlorofil contained in tamarind leaves as chlorophyll would interfere at absorbance readings. $\mathrm{N}$-hexane solvents were selected as chlorophyll is insoluble in water. However, it can dissolve in various types of organic solvents ${ }^{10}$; thus, it can be seen that chlorophyll is non-polar, while solvents are chosen to have the same properties as chlorophyll. The residue from maceration was then added with $70 \%$ ethanol until the entire powder was submerged. The filtrate was then evaporated using a rotary evaporator at $60^{\circ} \mathrm{C}$ with a speed of $80 \mathrm{rpm}$ to separate the extract from the solvent. The extract obtained was then evaporated again using a water bath at a temperature of $60^{\circ} \mathrm{C}$ until a thick extract was obtained. The thick extract obtained was 11.98 grams. The extract yield was calculated by comparing the weight of the thick extract with the weight of dry simplicia in percent. ${ }^{11}$ The calculation of extract yield aimed to estimate the amount of material to be used to obtain the desired amount of extract. The yield value of tamarind leaf extract obtained was $9.74 \%$.

Determination of the maximum wavelength is needed to increase sensitivity and minimize errors when it repeated measurements. ${ }^{12}$ In this study, the determination of maximum wavelength was carried out using a standard solution of a quercetin concentration of 100 ppm, which was measured in the wavelength range of 200-800 $\mathrm{nm}$ using UV-Vis spectrophotometry. The measurements were carried out at that range as sibling UV, and visible rays had wavelengths ranging from $200-800 \mathrm{~nm}$. Based on optimization screening results, the maximum wavelength found two-peak spectra at $210 \mathrm{~nm}$ and $361.8 \mathrm{~nm}$ (Figure 1). Ethanol, as a solvent, is known to have maximum absorption at a wavelength of $210 \mathrm{~nm} .{ }^{13}$ Therefore, it can be concluded that the maximum wavelength of quercetin was $361.8 \mathrm{~nm}$. Meanwhile, other studies showed that quercetin has a maximum wavelength of $380 \mathrm{~nm}^{14}$

A standard curve was carried out by using a standard solution of quercetin with series concentrations of $4 \mathrm{ppm}, 6 \mathrm{ppm}, 8$ ppm, $10 \mathrm{ppm}$, and $12 \mathrm{ppm}$. The absorbance results obtained from each series of concentrations were then made linear regression line equations, which can be used to calculate the quaternary levels of quercetin in the tamarind leaf extract. The results of the quercetin standard curve are shown in Figure 2.

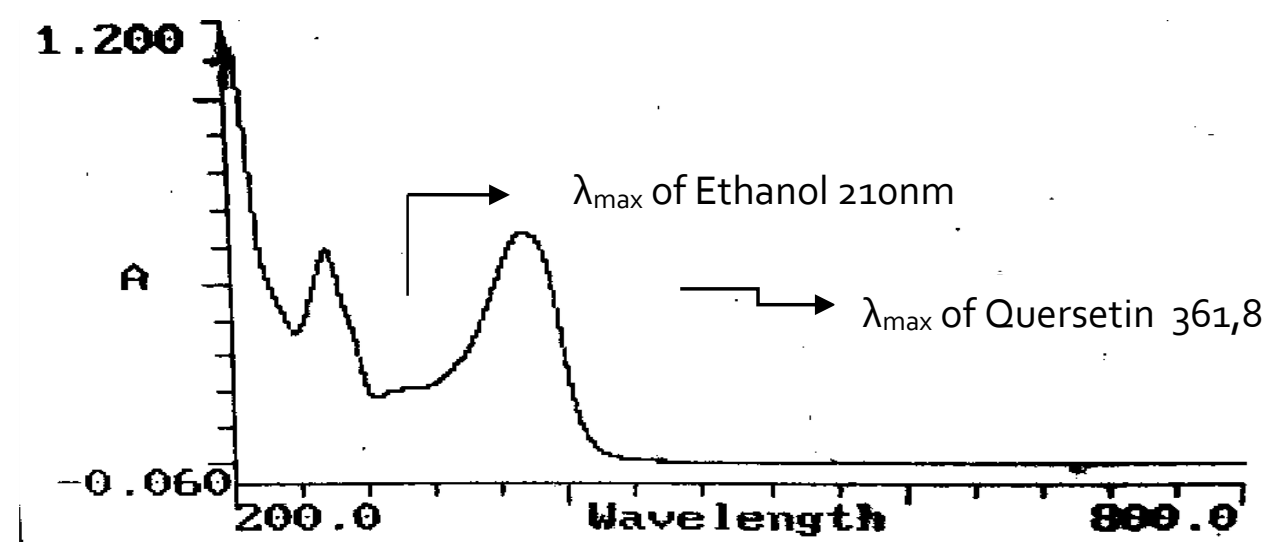

Figure 1. Determination of quercetin maximum wavelength 


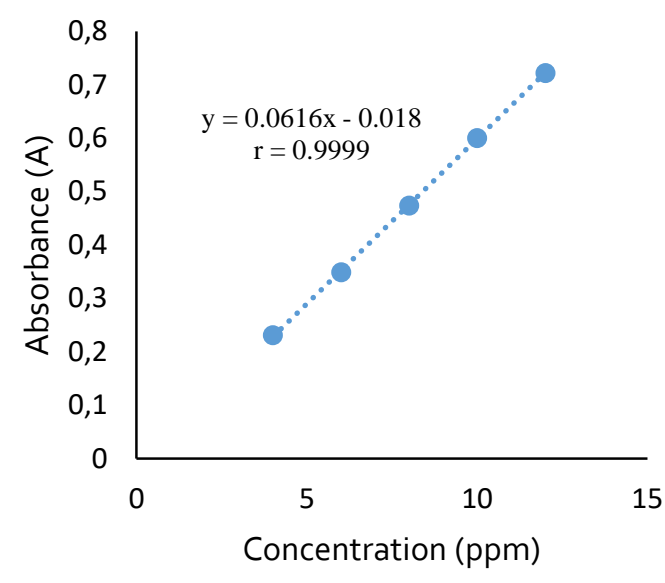

Figure 2. Quercetin standard curve

The results of the quercetin standard curve obtained the intercept axis value 0.0616 and the slop value of -0.018 ; thus, the linear regression line equation derived was $y=0.0616 x-0.018$.

Determination of quercetin levels was carried out using a solution of tamarind leaves extract with a concentration of 500 ppm. The test was carried out three times, and it then calculated the average level of quercetin in the tamarind leaf extract. The results of level measurements are shown in Table 1. Quercetin levels can be calculated by processing data from the results of absorption measurements with the linear regression line equation $y=0.0616 x-$ 0.018 . The measurement results showed that quercetin levels were $10.76 \mathrm{ppm}$ in $500 \mathrm{ppm}$ tamarind leaf extract; thus, it can be seen that in 1 gram of tamarind leaf extract, there was $21.52 \mathrm{mg}$ quercetin. Measurement of this level can be useful to determine the amount of tamarind leaf extract needed in producing drugs with natural ingredients so that the desired pharmacological effect can be achieved.

Validation of the assay method is conducted to ensure that the analytical methods are accurate, specific,
Table 1. Quercetin levels in tamarind extracts

\begin{tabular}{ccc}
\hline Replication & $\begin{array}{l}\text { Absorbance } \\
\text { (A) }\end{array}$ & $\begin{array}{l}\text { Quercetin } \\
\text { Levels (ppm) }\end{array}$ \\
\hline 1 & 0.645 & 10,763 \\
2 & 0.644 & 19,747 \\
3 & 0.645 & 10,763 \\
\hline & $\bar{x}$ & 10.758 \\
\hline
\end{tabular}

reproducible, and resistant to the analyte range to be analyzed ${ }^{15}$. The validation parameters of the method observed in this study are as follows:

Linearity is conveyed in terms of variance around the direction of the regression line, which is calculated based on mathematical equations of data obtained from the test results of analytes in samples with various series of concentration analytes. ${ }^{6}$ The parameter used in linearity testing is the correlation coefficient $(r)$ in linear regression analysis $y=a+b x$. The linear test results are shown in Table 2 . The linear regression line equation obtained is $y=0.0616$ $0.018 x$ with a correlation coefficient $(r)$ o.9999. Linearity can also be determined by calculating the value of $\mathrm{V}_{\mathrm{xo}}$, which is $0.59545 \%$. Based on the results of the correlation coefficient and the calculation of $V_{x o}$ it can be seen that the spectrophotometric method has good linearity for $V_{x o}$ value is $\leq 5 \%$ with a correlation coefficient of $0.9999 .{ }^{16}$

Table 2. Linearity of quercetin

\begin{tabular}{lc}
\hline Concentration (ppm) & Absorbance (A) \\
\hline 4 & 0.231 \\
6 & 0.349 \\
8 & 0.474 \\
10 & 0,600 \\
12 & 0.722 \\
\hline Slop (b) & $-0,018$ \\
Intercept axis (a) & 0.0616 \\
Correlation coefficient $(r)$ & 0.9999 \\
\hline
\end{tabular}


Limit of Detection is the smallest number of analytes in the sample, which still gives a significant response compared to others. Limit of Detection is a limit test parameter. Meanwhile, the limit of Quantification can be interpreted as the smallest quantity of analytes in a sample that had fulfilled the criteria of precision and accuracy ${ }^{6}$. The LOD and LOQ can be calculated statistically based on the standard deviation response and the standard slope (S) curve. LOD results obtained in this test are $0.1515 \mathrm{ppm}$. The LOO results obtained were 0.4592 ppm. The result showed that the standard curve and the determination of quercetin content in tamarind leaf extract had fulfilled the LOD and LOO parameters as the standard curve used the lowest concentration of $4 \mathrm{ppm}$ and quercetin levels above the LOD and LOQ values of 9.34 ppm in $500 \mathrm{ppm}$ tamarind leaf extract.

A precision method was conducted repeatedly by the same analyst in a shorter time interval; thus, the precision can also be described as repeatability or reproducibility. Precision was measured as a standard deviation or coefficient of variation ${ }^{6}$. Precision parameters were carried out using various series of concentrations in making quercetin raw curves, namely 4 ppm, 6 ppm, 8 ppm, 10 $\mathrm{ppm}$, and $12 \mathrm{ppm}$. The precision results in this study are shown in Table 3. It shows that the variation of coefficient values of each concentration has a value of less than $2 \%$.

Accuracy is a measure that shows the degree of closeness of the analyst's results to the actual levels of analyte. Accuracy is described as a percentage of the recovery. Accuracy testing performed in this study is a standard addition method for the tested compounds suk terms of secondary metabolite classes. Tests were carried out in the range of $80 \%, 100 \%$, and $120 \%$, with differences in extract concentrations and standard used. The range of $\%$ recovery received for analyte levels of more than $1 \%$ is $97-103 \%{ }^{6}$. The accuracy results in Table 4 show the value of percent recovery that has met the requirements. It indicates that the determination of levels using the spectrophotometric method fulfills the parameters of accuracy so that it can provide accurate results.

Table 3. Precision of quercetin

\begin{tabular}{cccccc}
\hline \multirow{2}{*}{ Replication } & \multicolumn{5}{c}{ Absorbance (A) } \\
\cline { 2 - 6 } & $\mathbf{4} \mathbf{p p m}$ & $\mathbf{6} \mathbf{p p m}$ & $\mathbf{8} \mathbf{p p m}$ & $\mathbf{1 0} \mathbf{p p m}$ & $\mathbf{1 2} \mathbf{~ p p m}$ \\
\hline 1 & 0.232 & 0.343 & 0.470 & 0.601 & 0.731 \\
2 & 0.226 & 0.343 & 0.476 & 0.594 & 0.716 \\
3 & 0.226 & 0.348 & 0.476 & 0.598 & 0.725 \\
4 & 0.229 & 0.349 & 0.474 & 0.607 & 0.716 \\
5 & 0.231 & 0.356 & 0.472 & 0.596 & 0.721 \\
6 & 0.235 & 0.353 & 0.471 & 0.604 & 0.724 \\
7 & 0.235 & 0.353 & 0.480 & 0.597 & 0.722 \\
$\bar{x}$ & 0.231 & 0.349 & 0.474 & 0,600 & 0.722 \\
CV (\%) & 1.629 & 1.452 & 0.736 & 0.779 & 0.731 \\
\hline
\end{tabular}


Table 4. Percent recovery of quercetin

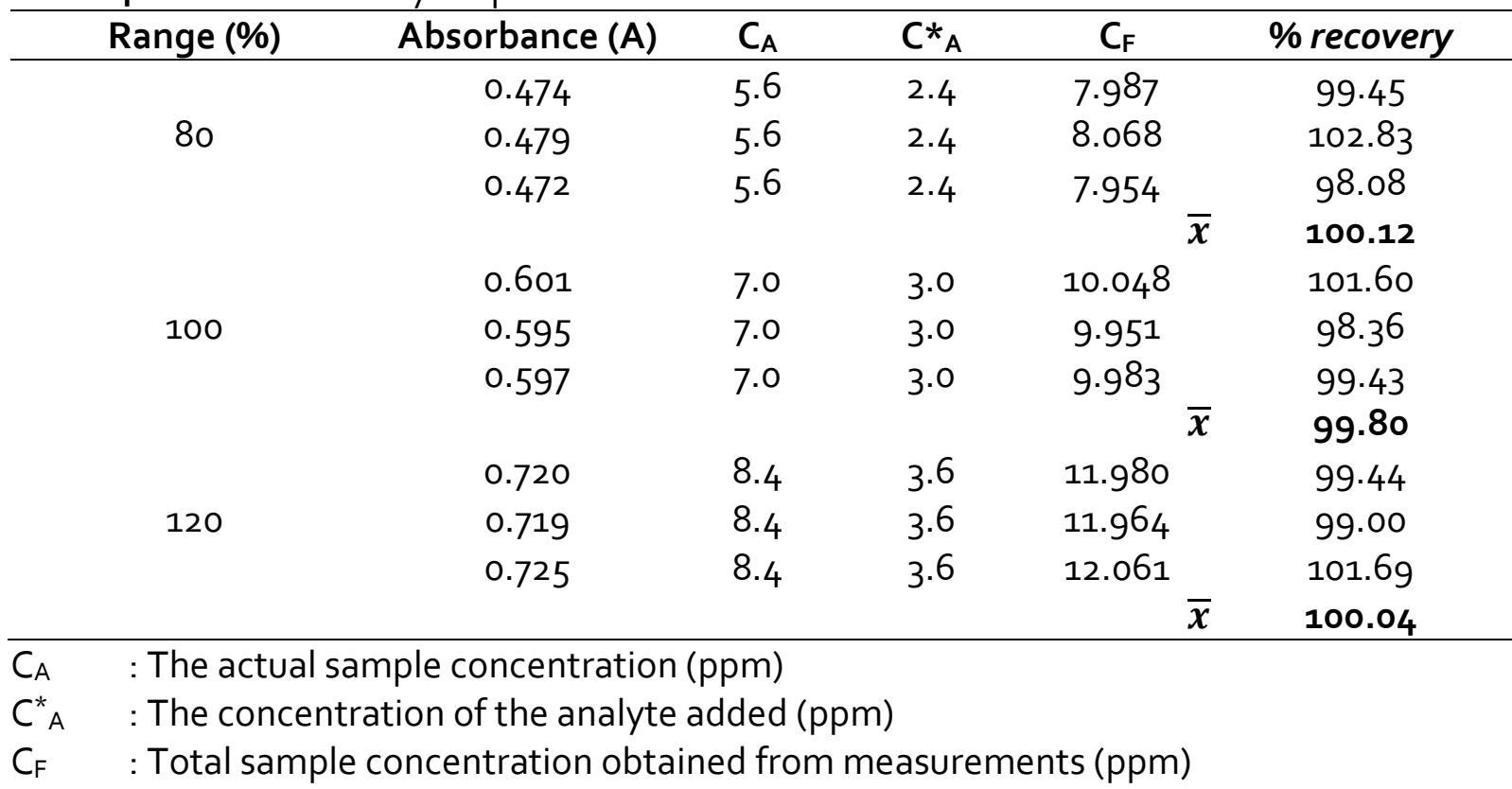

Based on the results of the study, it can be identified that the UV-Vis spectrophotometry method has fulfilled several parameters for the determination of the content of quercetin from tamarind leaf extract. These parameters are linearity, LOD, LOQ, precision, and accuracy.

\section{CONCLUSION}

Based on the results of the study, it can be concluded that the UV-Vis spectrophotometry method has fulfilled several parameters for the determination of the concentration of quercetin from tamarind leaf extract. The quercetin level in the extract in tamarind was $\mathbf{2 1 . 5 2}$ $\mathrm{mg}$ in $1 \mathrm{~g}$ extract. The correlation coefficient is 0.9999, and the regression function coefficient $\left(\mathrm{V}_{\mathrm{xo}}\right) \leq 5 \%$ is $0.59545 \%$. The LOD is $0.1515 \mathrm{ppm}$, and LOO is $0.4592 \mathrm{ppm}$. The variation coefficient values for precision parameters have been less than $2 \%$. Meawnhile, the accuracy values have a range of $97-103 \%$.

\section{ACKNOWLEDGMENT}

The authors would like to thank the Ministry of Research, Technology and Higher Education Republic of Indonesia (RISTEKDIKTI) for funding this research through the Beginner Lecturer Research grant in 2019.

\section{CONFLICT OF INTEREST}

There is no potential for conflict of interest.

\section{REFERENCES}

1. Fakhrurrazi, F., Hakim, R. F., \& Keumala, C. N. (2016). Pengaruh Daun Asam Jawa (Tamarindus Indica Linn) terhadap Pertumbuhan Candida Albicans. Journal of Syiah Kuala Dentistry Society, 1(1), pp. 29-34.

2. Doughari, J. H. (2006). Antimicrobial activity of Tamarindus indica Linn. Tropical Journal of Pharmaceutical Research,5(2), pp. 597-603.

3. Nwodo, U. U., Obiiyeke, G. E., Chigor, V. N., \& Okoh, A. I. (2011). 
Assessment of Tamarindus indica extracts for antibacterial activity. International Journal of Molecular Sciences, 12(10), pp. 63856396.

4. Kelly,

G. S. (2011). Quercetin. Alternative medicine review, 16(2), pp. 172-195.

5. Hendra, A. R. (2010). Isolasi dan Identifikasi Golongan Flavonoid Daun Dandang Gendis (Clinacanthus nutans) Berpotensi sebagai Antioksidan. [Skripsi]. Bandung: IPB.

6. Harmita, H. (2012). Petunjuk pelaksanaan validasi metode dan Cara Perhitungannya. Pharmaceutical Sciences and Research (PSR), 1(3), pp. 117-135.

7. Torbeck, L. (2010). Pharmaceutical and Medical Device Validation by Experimental Design.Journal of Validation Technology, 16(3), pp. 9-11.

8. Alwi, H. (2017). Validasi Metode Analisis Flavonoid dari Ekstrak Etanol Kasumba Turate (Carthamus tinctorius L.) secara Spektrofotometri. [Doctoral dissertation]. Makasar: Universitas Islam Negeri Alauddin Makasar.

9. Tetti, M. (2014). Ekstraksi, pemisahan senyawa, dan identifikasi senyawa aktif. Jurnal Kesehatan, 7(2), pp. 361367.

10. Riyono, S. H. (2007). Beberapa sifat umum dari klorofil fitoplankton. Oseana, 32(1), pp. 2331.
11. Pratomo, N. A., Yunita, E., Widyarini, S., \& Anshory, H. (2014). Efek Anti Angiogenesis Temu Kunci (Boesenbergia pandurata,(Roxb.) Schlecht) Pada Membran Korio Alantois Embrio Ayam Yang Diinduksi Basic Fibroblast Growth Factor (bFGF). Khazanah: Jurnal Mahasiswa, 6(2), pp. 35-45.

12. Yunita, E., Arifah, E. N., \& Tamara, V. F. (2019). Validasi Metode Penetapan Kadar Vitamin C Kulit Jeruk Keprok (Citrus reticulata) secara Spekteofotometri UVVis. PHARMACY: Jurnal Farmasi Indonesia (Pharmaceutical Journal of Indonesia), 16(1), pp. 118-131.

13. Moffat, A. C., Osselton, M. D., Widdop, B., \& Watts, J. (2011). Clarke's analysis of drugs and poisons (Vol. 3). London: Pharmaceutical press.

14. Bancirova, M. (2015). Changes of the quercetin absorption spectra in dependence on solvent. Chemistry Journal, 1(2), pp. 31-34.

15. Pharmacopeia, U. S. (2007). National Formulary 25. In Rockville, MD: US Pharmacopeial Convention (p. 1654).

16. Prabowo, M. H., Wibowo, A., \& Fauziyah, L. (2012). Pengembangan dan Validasi Metode Analisis Rifampicin Isoniazid-Pirazinamid dalam Fixed Dose Combination dengan Metode Kromatografi Lapis Tipis-Densitometri. Jurnal Ilmiah Farmasi, 9(2). 